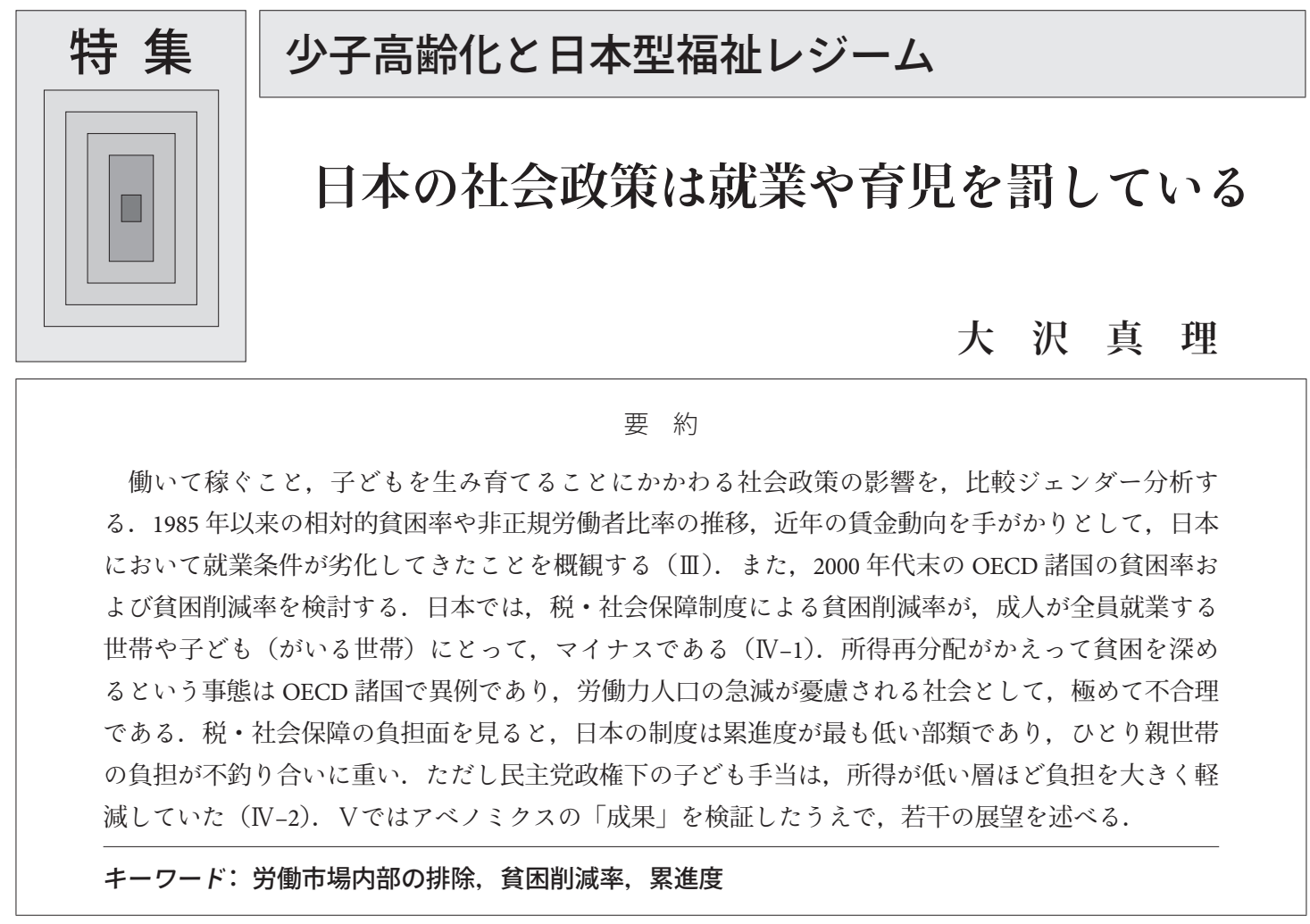

2015, 家族社会学研究, 27(1)：24-35

\title{
Social Policies Penalize Working and Child-Rearing in Japan
}

Mari Osawa

\begin{abstract}
This article tries to comparatively analyze the effects of social policies relating to working and child-rearing from a gender perspective. Trends of relative poverty rates and poverty reduction rates in Japan suggest that income redistribution through tax and social security schemes is not only ineffective in reducing poverty, but is actually deepening poverty for children and households where all adult members work (double-earning couples, and working lone parents and singles), while working conditions have been deteriorating. A negative figure in the poverty reduction rate is found in no other country of the OECD, an observation that is clearly problematic for a nation concerned by its low fertility rate and declining labor force. By examining the contributing side of income tax and social security, it can be seen that Japan has one of the least progressive schemes, the highest rate of net payment to government (income tax and employee's social security contributions less cash transfers) for lone parents in particular. The child benefit implemented by the DPJ government in 2010 and 2011 was effective in reducing rates of payment by households with children. Finally, certain outcomes of 'Abenomics' are examined and their policy implications discussed.
\end{abstract}

Key words: exclusion within labor markets, poverty reduction rates, progressivity

おおさわ まり：東京大学社会科学研究所

Institute of Social Science, University of Tokyo

E-mail: marosawa@sb4.so-net.ne.jp 


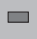

\section{I. はじめに}

日本家族社会学会の公開シンポジウム「少子高 齢化と日本型福祉レジーム」において, 私は, 本 稿と同タイトルの報告「日本の社会政策は就業や 育児を罰している」をおこなった。その主旨は， 日本の税・社会保障制度が，機能低下というより も「逆機能」している，というものだった。

その際に，つぎの点が前提となっていた，すな わち, 日本の社会保障制度において, セーフティ ネット機能が低下しているという認識, したがっ てその機能強化ひいては「モデル」の転換が必要 であるという意識は, 首相が任命するレベルの政 府の会議体においても，2008年から引き継がれ てきた。そうした認識や意識は, 2013 年 8 月に 安倍晋三首相に提出された社会保障制度改革国民 会議の報告書が述べたように，「2 回の政権交代 を超えて共有できる流れ」となっていたのである （社会保障制度改革国民会議 2013: 2)。しかし, 安倍内閣が 2014 年 6 月に閣議決定した「経済財 政運営と改革の基本方針 2014」では, 社会保障 の機能強化の方向性が希薄だった（閣議決定 2014a を参照).

以上を前提として, 報告では, 改めて逆機能へ の注目を促した。具体的には，まずつぎの 2 点を 論じた。（1）社会保険制度は失業・傷病・老齢退 職といったリスクをカバーすることを想定されて いるが, 日本では, 若者や女性が安定した労働市 場から排除される事態を招く場合が少なくない, （2）税・社会保障制度を通ずる所得再分配は，所 得格差や貧困を緩和することが期待されている が，日本ではかえって貧困率を高める場合が少な くない，このように，合理的と思われる想定や期 待に反する機能を，「逆機能」と称した。そのう えで報告では, 日本における税・社会保障の負担 面の特徵を検討した。

これらの趣旨を文章化した短い論文が，2014 年 11 月に公刊されている（大沢 2014b）。ただ し，公開シンポの報告でも同論文でも，アプロー
チや指標については最小限しか述べていない。ま た雇用就業の諸条件については, 社会保険制度の カバレッジの側面を論じ，賃金や雇用の実態につ いては，月別実質賃金指数の推移を紹介するに止 めた。

そこで本稿では，第 II 章で生活保障のガバナ ンスというアプローチと指標について述べる。そ のうえで第 III 章は, 全人口の相対的貧困率の推 移を手がかりとして, 雇用就業の条件の「劣化」 というべき状況を概観する，第IV章では，直近の 貧困率を，全人口，子どもがいて就業者がいる世 帯の人口, 労働年齢人口, などについて検討す る。そして，少なからぬ人びとにとって，所得再 分配による貧困削減の効果が，貧弱という以上に マイナスであることを再確認する（IV-1）。その 要因を探るべく IV-2では, 税・社会保障の負担 面の特徴を検討し，それらの検討結果を IV-3で まとめる．第 V 章ではむすびに代えて，アべノ ミクスの成果とされる事象を検証したうえで，若 干の展望を述べよう.

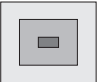

\section{II. 生活保障のガバナンスというアプ ローチ}

私は，この 10 年ほど，「生活保障システム」と いう枠組みで, 日本の社会経済状況を検討してき た。「生活保障システム」とは，税・社会保障制 度や労働政策といった政府の法・政策と, 企業や 家族・非営利協同組織などの民間の主体の制度・ 慣行が，相互作用し，かみあって（かみあわず に), 暮らしのニーズが持続的に充足される（さ れない）ことをさす．暮らしのニーズが持続的に 充足されている場合, 日々の生計がなりたち社会 参加できるというだけでなく，世代的な再生産も なりたつであろう。官民の多様なアクターが，意 識的にも無意識的にも相互作用しており，その 「効果の総体 (total effects)」を問う必要がある. 私は 2013 年末に出版した著作で，そうした効果 の総体に「ガバナンス」という概念を当てている （大沢 2013）. 
特集 少子高齢化と日本型福祉レジーム：日本の社会政策は就業や育児を罰している

生活保障システムでは, 職場や家族のあり方 に，性別役割や性別分業の標準や典型が，暗黙の うちにも措定されており, その意味でジェンダー が基軸になっている. 少なからぬ人びとにとっ て，暮らしのニーズが充足されないこと（プア・ ガバナンス）を，システムの機能不全ないし「逆 機能」の所産と捉え, その指標として「社会的排 除 (social exclusion)」の指標を取り入れている (大沢 2007, 2013; Osawa 2011).

周知のようにヨーロッパ連合 $\mathrm{EU}$ が 2001 年以 来採用している社会的排除の共通指標では, 低所 得という意味の「貧困リスク (at-risk-of poverty)」 や所得格差が重視されている．また雇用就業につ いては, 長期失業率とともに, 就業者がいない世

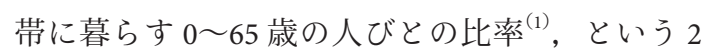
つが指標とされた (2). その後 2005 年までに, 第 2 次指標に「就業貧困 (in-work poverty) リスク」 がくわえられた（大沢 2011）。就業していても賃 金率が低すぎたり労働時間が不本意に短いなどの ために，低所得に陥る場合があることに留意した のである. 労働市場に参入しているとしても社会 的に包摂されているとは限らない, という問題意 識である(「労働市場内部の排除」).

日本でも労働市場内部での排除が重要である. III-2で触れるように，日本では正規のフルタイ ム雇用者とパートタイマーに代表される非正規雇 用者とのあいだに大きな処遇格差があり, 短時間 の雇用者は雇用主負担を伴う社会保険制度から排 除される。これらにかんがみて, 日本の非正規雇 用者の比率は, 労働市場の内部にいながら排除さ れている存在を代理的に表象すると考えられる.

本稿が手がかりとするのは, 経済協力開発機構 OECD が定義する「相対的貧困」という指標であ る.「相対的貧困」とは, 所得を世帯の規模につ いて均して「中央值」を求めたうえで，その中央 值の $50 \%$ 未満の低所得をさす（60\%や $40 \%$ も参 照される)。世帯の規模を均す手続きを「等価に する (equivalise)」といい, OECDでは, 世帯所 得を世帯員の人数の平方根で除して「等価所得」
を求めている，以下，相対的貧困を「貧困」と略 称する.

貧困率は通常は可処分所得レベルで測定される が, 参照のために市場所得レベルの数值が計測さ れることが少なくない。「市場所得」（当初所得と もいう）は, 雇用者所得, 事業者所得, 農耕・畜 産所得, 家内労働所得, 利子・配当金, 家賃・地 代, 仕送り, 雑収入, 企業年金給付等の合計であ る. 市場所得に社会保障の現金給付をくわえ, 直 接税と社会保険料負担を差し引いたものが，「可 処分所得」であり，間接税を別として政府が所得 再分配したのちの所得である.

市場所得から可処分所得への貧困率の変化は, 政府による所得再分配（間接税を除く）が貧困を 削減した程度を表す。貧困率の変化幅を市場所得 レベルの貧困率で割った数值を，(再分配による） 「貧困削減率」と呼ぶ。

市場所得レベルの貧困率は, 可処分所得レベル の貧困基準を市場所得の分布に当てはめて計算さ れる，それは仮想のものではあるが，重要な情報 を含んでいる. 市場所得レベルの貧困率は, 労働 市場や製品市場が作動してもたらす「分配」の特 徵の 1 つであり, 政府による所得再分配とは別 に，さまざまな収入の機会（政府が公共事業や産 業保護により稼得機会を作り出すことを含む）や 仕送りなどによって, 貧困が抑えられている程度 について (所得再分配の「機能的等価策 (functional equivalents)」), 情報を伝えている。市場所 得レベルの貧困率はまた, 保健医療や保育・介護 など, 社会保障による現物（サービス）給付が稼 得活動をサポートする効果も反映する.

市場所得レベルの貧困率はさらに, 政府がおこ なう所得再分配の性質や規模にも影響される。失 業手当や，育児休業の際の所得補償，年金給付な どが頼りになるものであれば，人びとには市場所 得が不要となる場合があり, 市場所得レベル（社 会保障の現金給付受けとり前）の貧困率は高くな るからである。そのような事象について, 福祉レ ジームの比較研究をリードしてきたイェスタ・エ 
スピン＝アンデルセンは, 福祉国家が（市場）収 入ゼロの人口を生み出す, と述べている（EspingAndersen and Myles 2009).

市場所得レベルの貧困率が高く, 貧困削減率も 高く, 結果として可処分所得レベルの貧困率が低 いということは, 政府による所得再分配のおかげ で，市場所得に依存せずに（労働市場でみずから を投げ売りするなどせずに), 貧困を免れること ができる程度を表すわけである。この, “政府に よる所得再分配のおかげで, 市場所得に依存せず に貧困を免れることができる程度”とは，エスピ ン＝アンデルセンが『福祉資本主義の三つの世 界』の「日本語版への序文」で述べた「脱商品化 (de-commodification)」の定義と重なる（エスピン =アンデルセン $1990=2001:$ iv). 市場所得と可処 分所得の 2 つレベルの貧困率は,「脱商品化」 の近似指標となりうると考えられるのである(3).

\section{III. 分配の劣化}

\section{1. 貧困率の推移一一簡単な国際比較}

そこでまず，いわゆる G5（フランス，ドイツ， 日本，イギリス，アメリカ）とスウェーデンおよ びデンマークについて, 全人口の貧困率の推移を 1985 年から 2009 年まで対比した結果を述べよ う. 市場所得レベルと可処分所得レベルの双方で 貧困率をたどり, あわせて貧困削減率の推移を見 たものである（大沢 2013: 208-11）.

特徵として留意したいのは, 第一に, 市場所得 レベルの貧困率では諸外国の数值がほぼ横ばいで あるなかで, 日本の数值は顕著に高まったことで ある.すなわち 1985 年の日本では $12.5 \%$ だった のにたいして，デンマークで $20 \%$ であり，その 他の諸国は $25 \%$ 超えていた. 当時の日本の数 值は，上記の諸国よりも有意に低かったわけであ るが，その後 2000 年代末には $32 \%$ になった。こ れは, フランス・ドイツにつぐ高さである.

第二に注目したい特徴は, 日本の可処分所得レ ベルの貧困率が, 国際的に見て低くない水準から 着々と高まってきたことである.1985 年の日本
の数值は $12 \%$ であって, 市場所得レベルの数值 と差がなく，その数值が $10 \%$ に満たないヨー ロッパ諸国よりも，有意に高かった。その後 2000 年代末では数值が $16 \%$ とアメリカに近づい た（OECD 諸国でも最も高いグループ）．そこで 第三に, 所得再分配による貧困削減率に目を転じ ると，1985 年の日本の数值はわずか $4 \%$ であり, その数值が $70 \%$ を超えるヨーロッパ諸国はもち ろん, アメリカの $30 \%$ と比べても低い. 1980 年 代の日本の所得再分配には, 貧困削減効果がない に等しかったということである.その後, 日本の 貧困削減率はある程度上昇し，2000 年代末では アメリカよりも高い $50 \%$ となったものの，ヨー ロッパのレベルからは，20\%程度低い．

したがって, 日本の市場所得レベルの貧困率が 高まったことは,「脱商品化」が進んだためとは いえない, 貧困削減率が高くなく, 可処分所得レ ベルの貧困率も高まったことと照らし合わせて, 日本における市場所得レベルの貧困率の上昇は, 「分配が劣化」したことを示す．そして可処分所 得レベルの貧困率の動向が示唆するのは, 税・社 会保障による所得再分配が分配の劣化を補正する 機能が，日本では貧弱である，という点である. 貧弱という以上に, 公開シンポでも強調し, 本稿 でも以下に述べるょうに, 就業者にたいしては所 得再分配が貧困率をかえって高めるという「逆機 能」を呈している。これは OECDの他の諸国に 類例を見ない事象と考えられる.

\section{2. 分配の劣化の背景}

分配の劣化の背景事情を列挙しよう。しばしば 指摘されるようにそれは, 経済成長率が低くなっ たこと, 失業率が高まったこと, 1985 年から女 性と若者で非正規雇用者の比率が高まってきたこ と，などである。

日本の失業率は 1990 年代初頭まで, 若年層 （15～24 歳）で 5\%前後, 壮年層（25～54 歳）で は $2 \%$ 前後と, 欧米に比べて格段に低かった。 そ れが 90 年代に入って上昇し, 2000 年代以来は若 年層で $8 \%$ 前後, 壮年層でも $4 \%$ 前後と, 80 年代 
特集 少子高齢化と日本型福祉レジーム：日本の社会政策は就業や育児を罰している

に比べて一段高いステージにある。それでもヨー ロッパ諸国よりは相当に低い（大沢 2013: 170-2）. 失業率が一段高いステージに定着した感がある ことは, 就業者に占める自営業者（業主と家族従 業者）の比率の低下と無縁ではないだろう．新雅 史は，戦後日本社会の「安定」を支えたのは，日 本型雇用慣行のもとで男性の雇用が安定していた ことだけでなく，商店街のような都市型自営業の 繁栄が重要だったと指摘している（新 2012: 1820)。また稲上毅によれば，1970 年代後半におい て日本の商工サービスの自営業主・家族従業者で は, 雇用者から自営に転じたものが相当の比重を 占めた（稲上 2005: 52-3）.つまり自営商工業が 縮小すれば, 雇用労働の就業機会の不足が失業と して顕在化しやすくなる.

実際に自営業者の比率は, 高度成長期には低下 したが，1970 年代半ばから 80 年代末までは $20 \%$ 程度を維持していた。 それが 90 年代以降に低下 してきた（大沢 2013: 173-4）. 日本の生活保障シ ステムにおいて, 日本型雇用慣行が軸の 1 つであ ることはまちがいないものの, それは, 自営業セ クターの維持という側面からの支えがあって機能 してきた，その側面の支えが失われたのである. そして失業率の上昇と併行して, 雇用者に占める 非正規の比率が, 女性と若年男性で上昇した. 反 面で, 2014 年でも 35〜 54 歳男性では 9 割という 正規比率を維持している (労働力調查詳細集計). いいかえれば，労働市場では「男性稼ぎ主」の生 活保障を優先的に図るように官民のアクターが相 互作用している（「男性稼ぎ主」型の生活保障シ ステム).

なお, 雇用者に占める非正規労働者の比率は, 2000 年代後半には男女とも上昇しなかった。リー マンショック後, 非正規の雇い止めが大量に起こ り, 非正規の比率が短期的に低下したという事情 もある.しかし, 労働力調査の詳細集計によれ ば, 2012 年から 14 年にかけては, 男女ともに非 正規比率が急上昇した。これは正規雇用者の実数 が減少したことに伴う動きでもある（2012 年 7〜
9 月期から 14 年 7〜9 月期までに 22 万人減少).

ところで, 非正規の比率や失業率, とくに若年 層の状態について, それらが雇用保護の強さと相 関するという分析がある. 分析から進んで, 日本 は若年層の雇用機会を拡充するためにも正規雇用 者の解雇からの保護を緩和すべきだと提言された こともある。しかし OECD の指標によれば，日 本の正規雇用者の解雇からの保護法制の強さは, 一貫して OECD 諸国の中位程度であって, 強く ない.いっぽう有期雇用の規制は弱いほうだった ものが，さらに緩和されてきた，日本の位置は 2000 年代半ばには, ニュージーランド, オース トラリア,アイルランドなどに近づき, その後は 正規の解雇からの保護の指標が低下して, いっそ う近くなった。しかも, 雇用保護が控えめなのに 非正規の比率が高いという点も, 日本の非正規雇 用の特徴である（大沢 2013: 176-7, 180）.

正規雇用者の解雇からの保護は, 法制上はすで に十分に弱い，それをさらに弱めれば，非正規化 に歯止めがかけられるとは到底考えられないので ある。

失業率の上昇と雇用の非正規化に伴うように, 平均顀金は低下してきた. 1995 年を 100 として, 2010 年までの 1 人当たり雇用者報酬の指数を諸 外国と対比すると，ドイツを除く欧米の主要国と 韓国では相当の伸びが見られるのにたいして (2010 年で OECD 平均は 167, 韓国は 215), 日本 のみ 89 とマイナスである（大沢 2013: 183）。雇 用者報酬には，現金給与総額だけでなく雇用主の 社会負担（社会保険料負担や企業年金への拠出, 退職一時金など）が含まれる.

OECD.StatExtracts の Taxing wages 欄によれば, 2000 年以来の社会保障負担率は, G5 やスウェー デンでは労使ともに横ばいないし低下気味であ り，1 人当たり雇用者報酬の伸びは現金給与の伸 びを反映すると見てよい.これにたいして日本で は, 社会保障負担率は労使とも一貫して上昇して いる.そこで日本について, 厚生労働省の毎月勤 労統計調査で, 従業員数 5 人以上の企業（調查産 
業計）の「常用労働者」について, 月々の「き まって支給する給与」の実質の指数（2010年の 平均＝100）を見よう。「常用労働者」にはパート タイム労働者の大部分を含む. その指数は, 福 田・麻生政権（2007 年 9 月〜 09 年 9 月）のもと でリーマンショックの以前から低下し, 民主党政 権（09 年 9 月〜 12 年 12 月）で 100 前後に戻した. それが 13 年 1 月からの安倍政権では顕著に低下 し, 14 年夏以降には 95 前後となった.

安倍政権のもとで非正規雇用者の比率が急上昇 したことと，パート労働者を含む平均賃金が低下 したことは，互いに整合する。複数の分析によれ ば，90 年代後半から最近にかけての名目平均賃 金の低下は, その 8 割程度がパートタイム労働者 の比率の上昇によって説明される。日本はフルタ イム雇用者とパートタイマーの時間当たり賃金の 格差が大きい国であり，しかも短時間のパートタ イム労働者を増やせば雇用主の社会保険料負担も 節減できる（厚生年金と健康保険の雇用主負担が 発生するのは, 週 30 時間以上就労の場合）（大沢 2013: 297-8, 352, 191-4).「男性稼ぎ主」を優遇す るような労働市場での相互作用だけでなく, 社会 保険制度の設計が，雇用の非正規化を促迫するの である。

グローバル競争のなかで, 途上国や比較的低賃 金の新興国の追いあげを受ける状況は, 日本に限 られず先進諸国に共通していると考えられるが, 実際に賃金が低下したのは日本だけである。正規 フルタイム雇用者の定期給与のカットではなく, 若者や女性のパート・アルバイトを中心とする非 正規の比率を増やすことで平均賃金が引き下げら れた。そして,アベノミクスは労働市場の内部に おける社会的排除をいっそう広げたのである。

\section{IV. 逆機能する所得再分配}

\section{1. 貧困削減率がマイナス一一成人が全員就業す る世帯にとって}

2000 年代末の OECD メンバー主要国のなかで, 全人口の可処分所得レベルの貧困率が高いのは,
アメリカ $(17.3 \%)$, 日本 (16\%), 韓国 (15.3\%), オーストラリア (14.5\%) であり, 南欧諸国でも 高い。他方で北欧と中・東欧諸国では 5\%から $8 \%$ 程度と低い。そしてフランスをはじめ大陸西 欧諸国も，おおむ称 $10 \%$ を下回る低い数值を示 している（大沢 2014a: 80）.

貧困率が低い国では貧困削減率が高いという傾 向があり（はずれるのはスイス）(大沢 2014a: 80）, そのように貧困を抑えこんでいる国では，公的社 会支出の対 GDP 比が高い（大沢 2013: 385）. そ して OECD の社会支出データベースが示すよう に，スウェーデンとデンマークをはじめとする北 欧諸国では, 2000 年代末の時点で, 医療以外の 社会サービス給付にGDP の相当部分（4\%ないし 7\%）をあてている.

スウェーデンとデンマークの推移を振り返る と, 両国では医療以外の社会サービス給付の対 GDP 比が，1980 年代から徐々に上昇している. 他方で現金給付の対 GDP 比は上昇しておらず, 公的社会支出の重心が現金からサービスへと移動 したことになる.医療以外の社会サービスのおも なものは, 家族支援 (就学前教育と保育), 積極 的労働市場施策，そして高齢者および障害者への サービスである。これらのサービスは, 次世代へ の投資であると同時に，労働年齢人口の稼得活動 をサポートするものである。両国では市場所得レ ベルの貧困率が，1995 年に比べて 2000 年代には 低下しており（2008 年まで）, 公的社会支出の重 心がサービス給付に移動したことと整合的であ る.

以上にたいして 2009 年の日本では, 上記のよ うに市場所得レベルの貧困率も高いほうである. そして, 公的社会支出の規模は OECD の平均よ りやや低く, 現金給付のなかでも年金（老齢・遺 族）に集中している（大沢 2013: 364,385）.

ところで，子どもがいて就業者がいる世帯の人 口の貧困率を，2000 年代半ばについて，世帯の 成人数と就業者数別に見ると，全人口とは図柄が 異なってくる.すなわちオーストラリアとイギリ 
特集 少子高齢化と日本型福祉レジーム：日本の社会政策は就業や育児を罰している

スで貧困率が北欧諸国並みに低く抑えられてお り, 日本のひとり親世帯の貧困率 $58.4 \%$ が断然 トップである。いうまでもなく，ひとり親の大多 数は女性である.また日本とともにトルコでは, 成人が 2 人以上いる世帯で就業者が 1 人でも 2 人 以上でも，貧困率にほとんど差がない。これら は,「第二の稼ぎ手」の稼得力が, 日本とトルコ では弱いことを反映しているだろう（大沢 2013: 381）。第二の稼ぎ手」の大多数も女性であろう が, 日本（とトルコ）で女性が追加的に働いて も, 貧困リスクが低下しないのは, 日本では稼得 力の問題だけではないことを, 以下に述べる.

つぎに, 世帯主が労働年齢（18 歳以上 65 歳未 満）の世帯に属する人口（以下, 労働年齢人口） について貧困削減率を見よう。労働年齢人口につ いては, 日本では貧困削減率がきわめて低いばか りでなく，マイナスになるケースが少なくない． 広く知られているように阿部彩は, 子ども（がい る世帯) について, 1985 年から 2009 年まで貧困 削減率がマイナスだったと指摘してきた（阿部 2006, 2014).

OECD の 2009 年の『雇用アウトルック』は, 労働年齢人口の貧困削減率について, ジェンダー 視点にとってきわめて示唆に富む分類をおこなっ た.すなわち 2005 年について, 成人の全員が就 業している世帯とカップルの 1 人だけが就業して いる世帯をとりだして, 所得再分配による貧困削 減率を示した。すると日本では, そして日本での み, 成人全員が就業する世帯にとって貧困削減率 がマイナスであり, 数值も $7.9 \%$ と無視できる程 度ではなかった（OECD 2009: Figure 3.9）。共稼ぎ 世帯や働くひとり親にたいして, 政府による所得 再分配がかえって貧困者を増やすのである.

子どもがいる世帯にかんして留意したように， 日本の働くひとり親世帯の貧困率は OECD 諸国 で断然トップであり, 成人が 2 人以上いる有子世 帯で「第二の稼ぎ手」がいても貧困リスクが低下 しない.これは，ひとり親や「第二の稼ぎ手」の 稼得力が小さいことによるばかりでなく, 日本で
は政府の所得再分配による貧困削減率が，これら の世帯にたいしてマイナスであることも反映して いるだろう。

いっぽう「男性稼ぎ主」（カップルの 1 人が就 業）世帯にとっては, 日本でも所得再分配による 貧困削減率がプラス $(6.7 \%)$ になっており, 鮮 明なコントラストをなしている（OECD 2009: Figure 3.9). ここにも, 日本の生活保障システム が「男性稼ぎ主」型であることが，現れている.

結果的に日本の貧困率は, 全人口だけでなく労 働年齢人口についても, OECD 諸国で最も高い部 類となっている.ちなみに日本の労働年齢人口の 貧困層では, 就業者が 1 人以上いる世帯が $83 \%$ を占めており，とくに就業者が 2 人以上いる世帯 が $40 \%$ を占める。このように, 「就業貧困」を通 り越して「共稼ぎでも貧困」の特徴があるのは, 日本のほか, アイスランドとトルコである（大沢 2013: 373-81).「共稼ぎでも貧困」となるのは, 夫婦ともに稼ぎが貧弱であるためかもしれない が, 日本においては政府の所得再分配が共稼ぎ世 帯の貧困率を高めているという事態の影響でもあ るだろう。

2000 年代後半にかんして OECD のデータが示 す状況は, 日本のより最近のパネルデータにもと づく研究によっても裏打ちされた。すなわち, 2009 年から開始された「日本家計パネル調査 (JHPS)」を, 駒村康平たちが分析した結果, 2009 年の日本で, 就業者では当初所得（市場所 得）レベルよりも可処分所得レベルにおいて相対 的貧困率が高いこと, このマイナスの効果が社会 保険料負担によって生じていたことが, 判明した のである（駒村ほか 2010）。

\section{2. 税・社会保障制度の累進度}

では日本の税・社会保障制度には，どのような 特徴があり，近年どのように変容したのだろう か. 駒村たちの分析でも示されたように, 貧困削 減率がマイナスになるような事態が示唆するの は, 税・社会保障拠出の負担面を検討する必要性 である。 
OECD の『タクシング・ウェイジズ』は, 2013 年版の特別記事で, 所得課税（国税および 地方税）とタックスウェッジ（個人所得課税十労 使の社会保険料負担一社会保障現金給付）の, 2011 年の平均負担率累進度を, 複数の世帯類型 について示した（OECD 2013）。 また 2014 年版の 特別記事では, 2000～12 年の累進度の変化を検 討している（OECD 2014）.

まず，ひとり親と子ども 2 人の世帯の税・社会 保障の純負担（所得課税十雇用者の社会保険料一 社会保障現金給付）が粗賃金収入に占める比率 (平均負担率) を, 日本をはじめとする数力国に ついて 2000 年から 2013 年までたどった結果を述 ベよう (くわしくは大沢 $2014 \mathrm{~b}$ を参照)。ひとり 親世帯に注目する理由は, 一般に他の世帯類型に 比べて貧困に陥るリスクが高いこと，上記のよう に, 日本の就業するひとり親世帯の貧困率は, OECD 諸国でも最も高いことにある。

ひとり親の収入は平均賃金の $67 \%$ に設定され ており，2013 年の日本については粗賃金収入で 326 万 7803 円と, 日本のひとり親としてはかな り高収入である（OECD 2014: 366） ${ }^{(5)}$ 。その収入 レベルのひとり親の純負担率において，第一の特 徵は, 日本が高いほうにあることである. 2013 年の数值 $12.7 \%$ は, OECD メンバー 34 カ国のな かでも 7 番目に高い。これにたいして単身やカッ プルの他の世帯類型では, 日本の負担率は低いほ うである。

第二に，オーストラリア，イギリス，アメリカ などで, 純負担率がマイナスで（になる場合が） あり，それは社会保障の現金給付（または給付つ き税額控除など）による受けとりが, 負担を上回 ることによる。第三に, 日本でも 2009 年の $11.3 \%$ から 10 年の $7.4 \%$ へと負担率が明確に低下 し（低下率にして $34.5 \%$ ), 順位も OECD メン バー34 カ国中第 14 位となった. 2011 年にも $8.4 \%$ と，10\%を下回っており，順位は 14 番目 だった。これは明らかに, 民主党政権が導入した 子ども手当の効果である（OECD 2010: 320; OECD
2011: 374).

自民党と公明党の要求によって子ども手当が 12 年度から（新）児童手当に変更されて金額が 減ったこと，および年 76 万円の年少扶養控除が 廃止されたこと（国税で 2011 年 1 月から，地方 税で 12 年 6 月から）をへて ${ }^{(6)}, 12$ 年の負担率は いっきょに $12.7 \%$ となり（上昇率にして $48 \%$ ), スウェーデンよりも高くなった（OECD 2012: 370; OECD 2013: 370; OECD 2014: 366).

つぎに直近の累進度を見よう。所得課税（と社 会保障負担）が高所得者にとって相対的に重い (社会保障の現金給付が低所得者に集中している) ならば，所得税（タックスウェッジ）の累進度が 高くなる，粗賃金収入を横軸にとり，当該収入レ ベルでの平均負担率をグラフにすると，ある収入 レベルまたはある収入間隔のあいだのグラフの傾 きが，累進度を表す。累進度はアングロサクソン 諸国で高く, 日本は各種の世帯類型を通じて, 税・社会保障制度の累進度が OECD 諸国でも最 も低い部類に属する（OECD 2013: Special Feature; OECD 2014: Special Feature).

本稿では, 純負担（所得課税十雇用者の社会保 障負担一社会保障現金給付）の率を, 日本, ドイ ツ, イギリス，オーストラリアの 4 カ国について 見よう。図 1 は, 子どもが 2 人いる世帯をひとり 親の場合と夫婦片稼ぎの場合に分け，参考のため に単身者も含めて, 粗賃金収入が平均顀金の 50\%から 250\%までについて，1 パーセント刻み で平均純負担率を示している。 カーブの勾配が累 進度を表す，見られるように，日本のカーブは若 干のポイントを除いて, 非常に平坦である。日本 の制度の累進度の低さは，イギリス・オーストラ リアはいうまでもなく，ドイツと比べても際立っ ているのである.

では累進度の推移はどうだろうか。『タクシン グ・ウェイジズ』2014 年版では, 2000 年と 2007 年および 2012 年のあいだの変化のみがとりあげ られていて, 年々の数值は掲載されていない. 日 本では，ひとり親と子ども 2 人の世帯で比較的低 

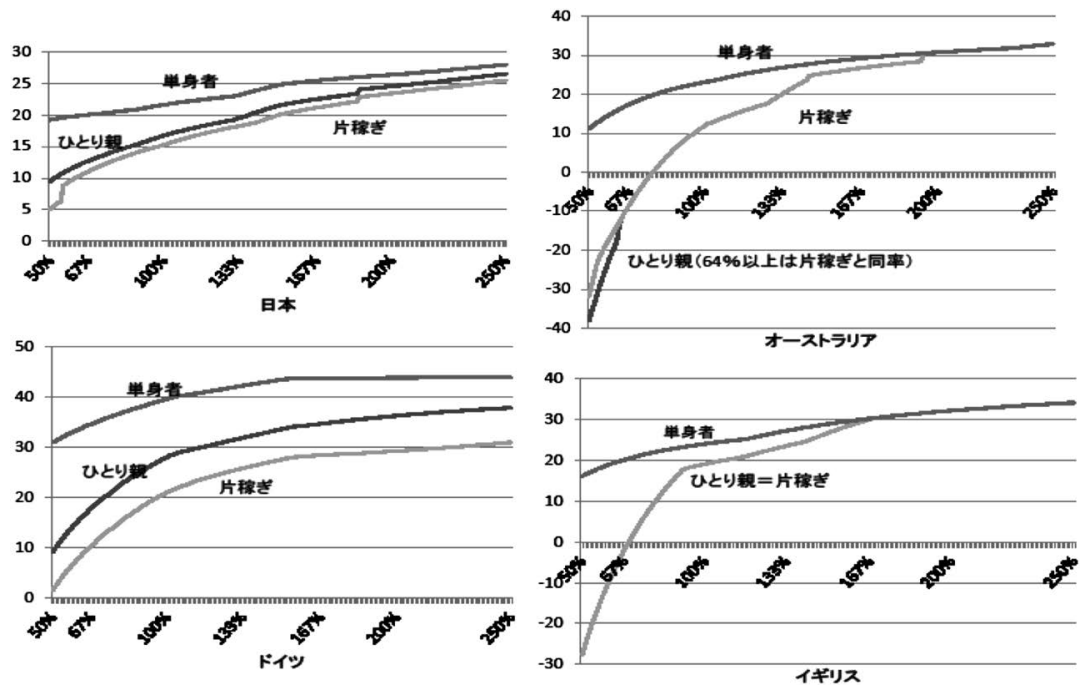

注：縦軸は純負担（所得課税十社会保険料一社会保障現金給付）が粗賃金収入に占める比率 (\%), 横軸は粗雑賃金 収入 (平均賃金対比)。イギリスのひとり親と片稼ぎ夫婦世帯の純負担率は，表示の範囲内で全く同一である. 出所：OECD.StatExtracts, Taxing Wages の欄のデータより作成.

図1 2013 年の純負担率, 子どもが 2 人いる世帯（ひとり親, 片稼ぎ）と単身者

所得の場合に, 2000 年にたいして 11 年ではタッ クスウェッジの累進度が顕著に高まった（他の諸 国と比べて累進度自体は低い)。それは 12 年には やや低くなったが，2000年との対比ではまだ高 かった（大沢 2014b: 26）. 他の世帯類型や所得 層では, 日本の累進度に顕著な変化は見られない (OECD 2014: Figures SF).

歳入の対 GDP 比というマクロのデータで見れ ば，日本では 1990 年から税収が低下し，他方で 社会保障負担は一貫して上昇してきた. 税収が低 下したのは, 景気の停滞による所得の伸び悩みの ためという以上に, 高所得者・企業への減税を繰 り返したためである（大沢 2013: 242-3）。社会保 障負担は端的に逆進的であり,この動向は, 歳入 全体の累進度を相当に低下させたと考えるべきで ある.

\section{3. 本章のまとめ}

本章の 1 で触れたように, 全人口について, ア イルランドを除くアングロサクソン諸国では, 貧 困削減率がさほど高くなく, その結果として, 可
処分所得レベルの貧困率も低くない.ただし， オーストラリアとイギリスでは, 子どもがいて就 業者がいる世帯の人口にとっては, 貧困率が北欧 諸国並みに低い。アングロサクソン諸国は，累進 的な税・社会保障制度をもつけれど，全人口の貧 困率が低くないのは，公的社会支出の規模が小さ いことと関連しているだろう。そのように相対的 に小規模の公的社会支出で, 子どもがいて就業者 がいる世帯の貧困率を北欧並みに抑えていること は，子育てと就業のインセンティブを増進できる ものであり，効率的であるといえよう.

他方で北欧諸国，そしてフランスを含む大陸西 欧諸国では, 累進度は高くないものの, 公的社会 支出の規模は大きく, 貧困削減率は高く, 貧困率 は全般的に低く抑えられている。 そのうち，デン マークとスウェーデンをはじめとする北欧諸国で は, 公的社会支出のなかで就学前教育や積極的労 働市場政策といったサービス給付の比重を高める 動きが見られる。これはアングロサクソン諸国と は異なる方法で，子育てと就業を支援するものと 
いえるだろう。エスピン＝アンデルセンの本来の 定義での脱商品化を維持しつつ, 労働力をディー セントな（働きがいのある人間らしい）条件で商 品化できるように環境を整え, 貧困の発生を予防 しょうとしていると理解できる。

これにたいして日本では, 公的社会支出の規模 は OECD 平均をやや下回る程度であり, 税・社 会保障制度の全般的な累進度は, 各種の世帯類型 を通じて, 最も低いグループに入る. 逆進的な社 会保障負担が高まっており, 子どもがいる世帯や 世帯の成人が全員就業する世帯にとって, 所得再 分配が貧困を削減する効果がきわめて貧弱であ る. 限りある所得再分配の資金を有効に充当でき ず，効果が貧弱どころか貧困削減率がマイナスと なるケースが少なくないのである.

ところで日本政府は, 貧困率の削減を所得再分 配の明示的な目標としてきたわけではない。とい うより政府は, 日本社会に貧困が存在すること自 体を，2009年まで認めていなかった（大沢 2013: 26). 同年 9 月に民主党政権が発足すると，まも なく長妻昭厚生労働大臣が貧困率を公表したもの の, 削減目標は立てていない. 2014 年 8 月 29 日 に安倍政権が閣議決定した「子どもの貧困対策大 綱」でも, 子どもの貧困率が指標とされてはいる が, 削減目標は掲げられていない（閣議決定 2014b).

それでも，日本では少子化による人口減少，な かでも労働力人口の減少が憂慮されている。その ような社会で, 子どもがいる世帯, 世帯の成人全 員が就業している世帯, あるいは就業者全般に とって, 貧困削減率がマイナスになっている，子 どもを生み育て，世帯として目いっぱい就業する ことが, 税・社会保障制度によっていわば罰を受 けているのである。本稿の題目の意味はここにあ る. 労働力人口の減少が憂慮される社会として, 生活保障システムが逆機能し, バッド・ガバナン スをもたらしているといわざるをえないだろう。

本章の 2 では, ひとり親世帯を中心に, 所得課 税と社会保障拠出（マイナス社会保障現金給付）
の純負担率の推移を比較することを通じて, 逆機 能の要因とともに，それを解消する政策手段につ いても一定の示唆が得られた。 2000 年代の日本 で子どもにかんする現金給付が少しずつ拡充さ れ，2010年に「子ども手当」が導入された結果 として, 2011 年時点でひとり親と子ども 2 人の 世帯の純負担率は，8.4\%まで下がっていた。「子 ども手当」は，限りある所得再分配の資金の使い 方として，効率的だったと考えられる。

「子ども手当」は親の所得による給付制限を伴 わなかった点で, 野党 (自民党, 公明党など) や マスメディアによって「バラマキ」と批判され た。しかし，「バラマキ」という批判論は, 貧困 率や累進度の動向に照らして検証されなければな るまい。

新児童手当への変更と年少扶養控除の廃止によ り,ひとり親世帯の純負担率は, 2012 年には $12.7 \%$ と, 前年より $4 \%$ ポイント高くなった. 2014 年 7 月 15 日に厚生労働省が報道発表した 「平成 25 年国民生活基礎調査の概況」によれば, 2012 年の日本の貧困率（全人口）は, $16.1 \%$ と過 去最悪を更新した。とくに子どもの貧困率は $16.3 \%$ と, 初めて全人口の数值を超え, またひと り親世帯に属する人口の貧困率は $54.6 \%$ と, 前回 2009 年の值から $4 \%$ ポイント近く高まった（厚生 労働省 2014). 本稿で見てきたひとり親世帯の純 負担率の変化と, その貧困率の急上昇とは整合的 である。

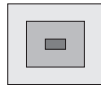

\section{V. むすびに代えて——アベノミクス の「成果」とは}

以上の 2013 年までの経緯に照らして，アべノ ミクスをどう見たらいいだろうか.「経済財政運 営と改革の基本方針 2014」も，超高齢化や人口 減少といった現象を無視しているのではない. 「アベノミクスのこれまでの成果」をうけて今後 には 4 つの重要課題があると述べ，その 1 つが 「人口急減・超高齢化」の流れを変えることであ る, という。 
特集 少子高齢化と日本型福祉レジーム：日本の社会政策は就業や育児を罰している

「アベノミクスのこれまでの成果」としてあげ られたのは，実質 GDP が成長したこと，デフレ 脱却に前進していること, 雇用情勢としても求人 倍率や賃金引き上げ率が伸びていること，などで ある（内閣府 2014）。成果を上げている成長戦略 をさらに推進し，「持続的・安定的な成長軌道」 に乗るために,「人口急減・超高齢化」の流れを 変える必要がある，という。そのために「あらゆ る分野の制度・システムを」,「結婚しやすく子育 てしやすい環境を実現する仕組みになっているか という観点から見直し」，「子どもへの資源配分を 大胆に拡大」する（閣議決定 2014a: 5, 10）, と 謳っている，つまり同基本方針は, 経済成長のた めの少子化対策を打ち出している.

だが本稿の III-2で見たように, 安倍政権のも とでは雇用の非正規化が加速し, 実質平均賃金が 低下した。労働市場内部での排除が進み, 子ども の貧困対策大綱は貧困率の削減目標を掲げていな い。ではそもそも経済成長は実現したのだろう か.

内閣府の GDP 統計によって, 数年間の四半期 ごとの実質成長率を見ると（季節調整系列で前期 比を年率換算), 安倍政権発足直後の 2013 年 1〜 3 月期こそスタートダッシュしたように見えた が，すぐに失速し，13 年 10〜 12 月期には年率で マイナス $1.6 \%$ となっていた. その後, 14 年 1〜3 月期のプラス成長を別として，14 年 4〜6 月期の マイナス $6.4 \%$, 同 7〜9 月期のマイナス $2.8 \%$ と, マイナス成長が続いている. 14 年度中の GDP の 落ち込みは, 消費税率引き上げ直前の「駆け込み 需要」の反動というだけで説明できるとは思われ ない。

これをうけて安倍首相は, 2015 年 10 月に予定 されていた消費税率の再引き上げ（8\%を10\%に） を 1 年半先送りすることを決断した。アべノミク スのこれまでの成果と今後の成算について国民の 「信を問う」として, 衆議院を解散した。選挙結 果は, 与党である自民党・公明党が議席数の 3 分 の 2 を維持するというものだった。歴史的に低い
投票率ながら，アベノミクスは信認された格好で ある。つまり，消費税率の再引き上げを先送りす れば，成長軌道に乗ると期待されたかのごとくで ある。

実際には賃金が（消費も）低迷しており，消費 税率を 2017 年 3 月末まで据え置いても, 景気が よくなる保証はない。しかも, 消費税率の再引き 上げが延期されたことにともない，2015 年度当 初予算案では, 介護サービスの公定価格や生活保 護の給付引き下げ，幼児教育の一部無償化の見送 りなどが，目白押しになっている（『朝日新聞』 2015 年 1 月 12 日朝刊, 『毎日新聞』 2015 年 1 月 12 日朝刊).

安倍政権の動向にたいして本稿は, 逆機能（に よるバッド・ガバナンス）の状況は，希望をも孕 むという点を強調したい，貴重な財源が，非効率 を通り越し，合理的に期待される機能とは逆の結 果をもたらしているのである. 生活保障システム のガバナンスを改善するために, 消費税率を再度 引き上げ，国民の税・社会保障負担を高めること が不可避なのではない, ということである.

安倍政権が「結婚しやすく子育てしやすい社 会」（骨太の方針 2014）の構築に真に取り組み, 貧困の世代間連鎖をくいとめる（子どもの貧困対 策大綱）というなら, 若者やひとり親の生活の窮 状を直視し，アベノミクスの微修正に止まらない 方向転換こそが必要であろう.

\section{【注】}

（1）つぎの世帯以外の世帯の人口に占める比率で ある. 18 歳未満者のみの世帯, 18〜24 歳の就 学者で就業していない者のみの世帯, 高齢者 のみの世帯 (Social Protection Committee 2001: 7).

（2）教育や健康にかんする指標も含まれている（大 沢 2011).

（3）エスピン＝アンデルセンの「脱商品化」の指 標が問い直されてきたことにつき，拙著を参 照されたい（大沢 2013: 106-13）．操作化には 問題があったとはいえ,「脱商品化」概念その ものは有効であると私は考えている. 
（4）そこには, 自営業者・失業者・年金生活者の 状況が含まれないだけでなく, 雇用者の社会 保険にカバーされない短時間雇用者などの状 況も反映されていない.

（5）等価可処分所得は 164 万 7570 円となる.「平 成 25 年国民生活基礎調査の概況」によれば, 2012 年の等価可処分所得 (名目) の中央值は 244 万円である. 労働年齢のひとり親世帯の人 口のうち, 8 割近くの等価可処分所得は 165 万 円に届かないと見てよい（http://www.mhlw.go. jp/toukei/saikin/hw/k-tyosa/k-tyosa13/dl/03.pdf).

（6）北明美は，（旧）児童手当，子ども手当，（新） 児童手当を緻密に比較検討しているので参照 されたい(北 2014).

\section{【文献】}

阿部彩, 2006, 「貧困の現状とその要因——1980 年代〜 2000 年代の貧困率上昇の要因分析」小塩隆士 ・田近 栄治・府川哲夫編『日本の所得分配一一格差拡大と 政策の役割』東京大学出版会, 111-37.

—， 2014, 『子どもの貧困 II 一一解決策を考える』 岩波書店.

新雅史, 2012,『商店街はなぜ滅びるのか一一社会・政 治・経済史から探る再生の道』光文社.

エスピン＝アンデルセン, イェスタ（岡沢憲芙・宮本 太郎監訳)， $1990=2001$,『福祉資本主義の三つの世界 ——比較福祉国家の理論と動態』ミネルヴァ書房.

Esping-Andersen, G. with John Myles, 2009, “The Welfare State and Redistribution," W. Salverda, B. Nolan \& T. Smedding eds. The Oxford Handbook of Economic Inequality, Oxford: Oxford University Press.

稲上毅, 2005,『ポスト工業化と企業社会』ミネルヴァ 書房.

閣議決定, 2014a,「経済財政運営と改革の基本方針 $2014 」 2014$ 年 6 月 24 日.

—，2014b，「子供の貧困対策に関する大綱一全 ての子供たちが夢と希望を持って成長していける社 会の実現を目指して」2014年 8 月 29 日.

北明美，2014,「社会政策の結節点としての児童手当制 度とジェンダー」『社会政策』5(3): 38-61.
厚生労働省，2014，「平成 25 年国民生活基礎調查の概況」 (2015 年 1 月 31 日 取得, http://www.mhlw.go.jp/toukei/ saikin/hw/k-tyosa/k-tyosa13/dl/03.pdf).

駒村康平・山田篤裕・四方理人 - 田中聡一郎, 2010, 「社会移転が相対的貧困率に与える影響」樋口美雄・ 宮内環・C. R. McKenzie・慶應義塾大学パネルデータ 設計・解析センター編『貧困のダイナミズム——日 本の税社会保障・雇用政策と家計行動』慶応義塾大 学出版会, 81-101.

内閣府, 2014,「「経済財政運営と改革の基本方針 2014」 のポイント」（2015 年 1 月 31 日取得, http://www5.cao. go.jp/keizai-shimon/kaigi/cabinet/2014/item_01.pdf 別紙) OECD, 2009, Employment Outlook, Tackling the Jobs Crisis, OECD.

- ,2010, Taxing Wages 2008-2009, OECD.
, 2011, Taxing Wages 2009-2010, OECD.
, 2012, Taxing Wages 2011, OECD.
- 2013, Taxing Wages 2013, OECD.
- 2014, Taxing Wages 2014, OECD.

Osawa, Mari, 2011, Social Security in Contemporary Japan, A comparative analysis, London and New York: Routledge/ University of Tokyo Series.

大沢真理，2007,『現代日本の生活保障システム——座 標とゆくえ』岩波書店.

- 一, 2011,「社会的経済の戦略的意義—EUと日 本の 2000 年代経済社会ガバナンスを対比して」大沢 真理編『社会的経済が拓く未来一一危機の時代に「包 摂する社会」を求めて』ミネルヴァ書房, 13-44.

—, 2013, 『生活保障のガバナンス—ージェン ダーとお金の流れで読み解く』有斐閣.

—, 2014a,「生活保障のガバナンス一一所得貧困 にそくして」『社会政策』5(3): 74-85.

—, 2014b,「日本の生活保障システムは逆機能し ている一一税・社会保障制度の累進性に焦点を当て て」『貧困研究』13: 17-28.

社会保障制度改革国民会議，2013，「社会保障制度改革 国民会議 報告書一一確かな社会保障を将来世代に 伝えるための道筋」 2013 年 8 月 6 日.

Social Protection Committee, 2001, Report on Indicators in the Field of Poverty and Social Exclusion. 